Jurnal Kebidanan Mutiara Mahakam, Vol 8 , No 2, Tahun 2020, Hal 77-83

ISSN : 2623-2553 (Online)

ISSN : 2549-0532 (Cetak)

\title{
HUBUNGAN DERAJAT KEPARAHAN AKNE VULGARIS DENGAN KUALITAS HIDUP MENGGUNAKAN DERMATOLOGY LIFE QUALITY INDEX (DLQI)
}

\author{
Alvin Sachio ${ }^{1}$, Vera Madonna Lumban Toruan ${ }^{2}$, Yuniati Yuniati ${ }^{3}$ \\ ${ }^{1}$ Program Studi Fakultas Kedokteran Universitas Mulawarman, Samarinda \\ ${ }^{2}$ Laboratorium Ilmu Kesehatan Kulit dan Kelamin Fakultas Kedokteran Universitas \\ Mulawarman, Samarinda \\ ${ }^{3}$ Laboratorium Mikrobiologi Fakultas Kedokteran Universitas Mulawarman, Samarinda \\ Email:alvinsachiol@gmail.com,veramadonnatoruan@yahoo.com,yuni_anas@yahoo.com \\ Dikirim : 20 Februari 2020 \\ Diterima : 1 Agustus 2020 \\ Diterbitkan : 3 September 2020
}

\begin{abstract}
Quality of life is an individual's perception of his life in the context of culture and values in a place of residence with the relationship of goals, expectations, standards and concerns. Acne is a problem that can have an impact on a person's quality of life because of the shame felt by sufferers. To describe the relationship between severity degree of acne vulgaris with quality of life using the Dermatology Life Quality Index assessment. This research is an analytical observational research with cross sectional method and the sampling was chosen by purposive sampling. The sample size of this study was 60 respondents, assessing quality of life using the DLQI questionnaire instrument. Statistical test data indicate that there is no relationship between the severity degree of acne vulgaris with quality of life $(p=0,101)$. There is no correlation between the severity of acne vulgaris with quality of life using the Dermatology Life Quality Index (DLQI) assessment.
\end{abstract}

Keywords : Quality of Life, Acne Vulgaris, DLQI 
Jurnal Kebidanan Mutiara Mahakam, Vol 8 , No 2, Tahun 2020, Hal 77-83

\section{PENDAHULUAN}

Kualitas hidup adalah persepsi individu terhadap kehidupannya dalam konteks budaya dan nilai dalam tempat tinggal dengan hubungan tujuan, harapan, standar, dan kekhawatiran (WHO, 1997). Akne merupakan salah satu penyakit peradangan kronis pada folikel pilosebasea yang dapat berupa komedo, papul, pustul, nodul, dan kista (Sitohang and Wasitatmadja, 2016).

Akne merupakan kondisi yang dapat meninggalkan gejala sisa seperti skar dan gangguan pigmentasi. Hal ini dapat membuat penderita merasa cemas dan malu terhadap penampilan, sehingga mampu untuk menurunkan rasa kepercayaan diri dan menjadi depresi, akibatnya mampu mempengaruhi kualitas hidup seseorang. Pada angka kejadian akne vulgaris didapatkan 6-7\% berkeinginan untuk bunuh diri (Nazaya, Praharsini and Rusyati, 2018).

Akne vulgaris hampir menyerang seluruh populasi dunia terutama pada usia remaja dan dewasa muda, menurut penelitian sekitar $85 \%$ terjadi pada usia remaja (Zaenglein et al., 2008). Umunya akne muncul pada usia 12-15 tahun dengan puncak keparahan pada usia 1721 tahun (Sitohang and Wasitatmadja, 2016).

Sebesar $41 \%$ mahasiswa memiliki derajat stres yang tinggi, hal ini diakibatkan oleh mahasiswa yang merasa bahwa beban hidupnya bertambah akibat dari perubahan tanggung jawab yang lebih, mahasiswa mengalami stres oleh karena perubahan-perubahan yang terjadi dari lingkungan sekolah menjadi lingkungan perguruan tinggi (Maulina and Sari, 2018). Stres mampu untuk membuat akne vulgaris itu muncul meskipun belum diketahui secara pasti (Harahap, 2000). Penelitian oleh Nazaya, Praharsini, \& Rusyati (2018) di Universitas Undayana didapatkan sebesar $72 \%$ dari 385 responden mengalami gangguan kualitas hidup ringan akibat akne vulgaris.

\section{METODE}

Penelitian ini merupakan penelitian analitik yang mempunyai tujuan untuk mengetahui hubungan derajat keparahan akne vulgaris dengan kualitas hidup penderitanya.

Populasi pada penelitian ini adalah mahasiswa pendidikan S1 Universitas Mulawarman Samarinda. Sampel penelitian ini adalah penderita akne vulgaris yang memenuhi kriteria inklusi dan eksklusi. Kriteria inklusi sampel adalah menderita akne vulgaris; mahasiswa Universitas Mulawarman; bersedia ikut dalam penelitian dan menandatangani informed 
Jurnal Kebidanan Mutiara Mahakam, Vol 8 , No 2, Tahun 2020, Hal 77-83

consent. Kriteria eksklusi adalah memiliki penyakit kulit lain selain akne vulgaris; tidak mengisi data dengan lengkap.

Jumlah sampel pada penelitian adalah minimal 60 sampel dengan 20 sampel tiap derajat akne vulgaris. Pemilihan sampel memakai cara purposive sampling yang dilaksanakan dari bulan Desember 2019 - Januari 2020 dengan menggunakan uji statistik Kruskal-Wallis. Alur penelitian ini dengan memilih penderita akne vulgaris dengan kriteria inklusi dan eksklusi yang sudah ditentukan. Data yang dikumpulkan berupa informed consent dan kuisioner Dermatology Life Quality Index (DLQI) yang diisi oleh responden serta meminta foto wajah responden untuk dapat dilakukan diagnosis dan penilaian derajat keparahan akne oleh dokter spesialis kulit dan kelamin. Data disajikan dalam bentuk tabel.

HASIL

Karakteristik Responden berdasarkan Usia

Tabel 1 Distribusi Frekuensi Responden berdasarkan Usia

\begin{tabular}{cccccc}
\hline Karakteristik & Mean & Median & Modus & Min & Maks \\
\hline Usia & 19,68 & 20 & 19 & 17 & 23 \\
\hline
\end{tabular}

Berdasarkan data hasil penelitian dari 60 responden menunjukkan bahwa usia responden rata-rata adalah 19,68 tahun dengan responden terbanyak berusia 19 tahun dan didapatkan usia terendah 17 tahun dan usia tertinggi 23 tahun.

\section{Karakteristik Responden berdasarkan Jenis Kelamin}

Tabel 2 Distribusi Frekuensi Responden berdasarkan Jenis Kelamin

\begin{tabular}{lcc}
\hline Jenis Kelamin & Jumlah (n) & $\%$ \\
\hline Pria & 22 & 36.7 \\
Wanita & 38 & 63.3 \\
\hline Total & 60 & 100 \\
\hline
\end{tabular}

Berdasarkan data hasil penelitian dari 60 responden menunjukkan bahwa responden pada penelitian ini terdapat 22 orang (36.7\%) pria dan 38 orang (63.3\%) wanita. 


\section{Analisa Hubungan Derajat Keparahan Akne Vulgaris dengan Kualitas Hidup DLQI}

Tabel 3 Hasil Tabulasi Silang Akne Vulgaris dengan DLQI

\begin{tabular}{cccccccc}
\hline & & \multicolumn{5}{c}{ Interpretasi DLQI } \\
\cline { 2 - 8 } & & $\begin{array}{c}\text { Tidak ada } \\
\text { pengaruh }\end{array}$ & $\begin{array}{c}\text { Pengaruh } \\
\text { kecil }\end{array}$ & $\begin{array}{c}\text { Pengaruh } \\
\text { sedang }\end{array}$ & $\begin{array}{c}\text { Pengaruh } \\
\text { besar }\end{array}$ & $\begin{array}{c}\text { Pengaruh } \\
\text { sangat } \\
\text { besar }\end{array}$ & Total \\
\hline \multirow{2}{*}{$\begin{array}{c}\text { Derajat } \\
\text { Akne }\end{array}$} & Ringan & $10(50 \%)$ & $3(15 \%)$ & $4(20 \%)$ & $3(15 \%)$ & $0(0 \%)$ & $20(100 \%)$ \\
\cline { 2 - 8 } & Sedang & $4(20 \%)$ & $11(55 \%)$ & $5(25 \%)$ & $0(0 \%)$ & $0(0 \%)$ & $20(100 \%)$ \\
\hline Total & Berat & $3(15 \%)$ & $7(35 \%)$ & $5(25 \%)$ & $5(25 \%)$ & $0(0 \%)$ & $20(100 \%)$ \\
\hline
\end{tabular}

Tabel 4 Nilai Signifikansi Akne Vulgaris dengan DLQI

\begin{tabular}{lc}
\hline & Derajat Akne \\
\hline Kruskal-Wallis H & 6.218 \\
\hline df & 3 \\
\hline Asymp. Sig & 0.101 \\
\hline
\end{tabular}

Pengolahan data yang dilakukan dalam analisis hubungan derajat keparahan akne vulgaris dengan kualitas hidup berdasarkan kuisioner DLQI pada tabel 4. Secara statistik pola hubungan tersebut diuji menggunakan uji analisis Kruskal-Wallis karena pada uji normalitas data Shapiro-Wilk hasilnya didapatkan signifikansi $0,000(\mathrm{p}<0,05)$ yang artinya data tidak terdistribusi dengan normal sehingga pada uji Multiple Regression tidak dapat dilakukan karena persyaratan untuk dilakukan uji adalah data harus terdistribusi normal. Pada tabel 4 dengan hasilnya berupa nilai signifikansi sebesar $0.101(\mathrm{p}<0,05)$. Sehingga dapat diartikan bahwa hipotesis yang menyatakan hubungan antara derajat keparahan akne vulgaris dengan kualitas hidup tidak dapat diterima.

Berdasarkan tabel 1 didapatkan hasil dengan rata usia responden yang mengalami akne vulgaris adalah 19,68 dan untuk data yang paling banyak pada usia 19 tahun. Hasil ini sesuai dengan penelitian terdahulu yang dipaparkan oleh Sitohang dan Wasitatmadja (2016) yang mengatakan bahwa akne vulgaris umumnya muncul pada usia 12-15 tahun dengan puncak tingkat keparahan pada usia 17-21 tahun akan tetapi akne vulgaris merupakan penyakit yang paling banyak pada usia 15-18 tahun (Sitohang and Wasitatmadja, 2016). Berdasarkan tabel tersebut, akne vulgaris merupakan suatu penyakit yang cukup sering muncul pada usia remaja 
Jurnal Kebidanan Mutiara Mahakam, Vol 8 , No 2, Tahun 2020, Hal 77-83

dimana pada usia remaja merupakan usia pubertas yang dapat mempengaruhi hormone di dalam tubuh sehingga dapat timbul akne vulgaris

Pada tabel 2 didapatkan hasil responden dengan jenis kelamin pria terdapat 22 responden (36,7\%) dan wanita sebanyak 38 responden (63.3\%). Hasil ini didapatkan dengan melakukan purposive sampling dengan jumlah minimal sampel sebanyak 60 responden. Hal ini sesuai dengan penelitian yang dilakukan oleh Adityan dan Thappa (2009) mengatakan bahwa dalam kelompok umur remaja wanita lebih banyak terdapat akne karena pada usia tersebut wanita lebih dahulu mengalami pubertas lebih dahulu daripada pria. Sehingga pada kelompok umur remaja yang sama dapat terjadi peningkatan kejadian akne pada wanita daripada pria secara keseluruhan (Thappa and Adityan, 2009).

Berdasarkan tabel 3 didapatkan hasil pada akne derajat ringan paling banyak responden tidak ada pengaruh kualitas hidup sebanyak 10 responden $(50 \%)$, pada akne sedang paling banyak responden mengalami gangguan kualitas hidup pengaruh kecil sebanyak 11 responden (55\%) , pada akne berat diapatkan hasil yang paling banyak responden yang mengalami pengaruh kecil pada kualitas hidup sebanyak 7 responden (35\%). Hal ini dapat terjadi karena banyak dari pertanyaan kuisioner yang tidak sesuai dengan penderita akne ataupun banyak jawaban "tidak sama sekali" pada penelitian ini. Terlihat pada pertanyaan 3 yang bertanya mengenai seberapa mengganggu akne terhadap kegiatan berbelanja, mengurus rumah atau pekarangan, dengan pertanyaan seperti itu maka jawaban responden "tidak sama sekali" atau pertanyaan tidak sesuai karena akne mungkin tidak menganggu kegiatan tersebut. Selain itu pertanyaan 6 juga menilai apakah ada gangguan berolahraga terhadap kelainan kulit yang diderita. Pada pertanyaan 9 yang menanyakan masalah seksual terhadap aken vulgaris, banyak dari responden yang menanyakan tentang maksud pertanyaan tersebut atau mungkin responden yang menjawab sesuai dengan pemahaman yang salah mengenai pertanyaan tersebut.

Pada penelitian yang dilakukan oleh Rahmatina (2013) mengatakan bahwa kuisioner DLQI mendapatkan hasil pengaruh besar dan sangat besar pada 10 orang dermatitis atopik dari total 20 penderita, 10 orang vitiligo dari total 20 penderita, 9 orang psoriasis dari total 20 penderita, dan 7 orang akne dari total 20 penderita. Dari hasil yang didapatkan bahwa kuisioner DLQI kurang cocok untuk digunakan dalam penilaian kualitas hidup penderita akne 
Jurnal Kebidanan Mutiara Mahakam, Vol 8 , No 2, Tahun 2020, Hal 77-83

(Rahmatina, 2013). Hal yang sama juga disampaikan oleh Yap (2012) bahwa DLQI dalam penilaian penampilan paling cocok dalam penilaian penyakit psoriasis (Yap, 2012).

Pada tabel 4 didapatkan hasil $\mathrm{p}=0,101(\mathrm{p}>0,05)$ yang berarti tidak terdapat adanya hubungan yang bermakna antara derajat keparahan akne dengan kualitas hidup menggunakan kuisioner DLQI. Pada beberapa penelitian akne vulgaris terdahulu yang menggunakan DLQI dalam menilai kualitas hidup juga dilaporkan hasil yang sesuai. Penelitian yang dilakukan oleh Nourmalydza (2016) yang mengatakan bahwa tidak adanya hubugan derajat akne dengan kualitas hidup menggunakan penilaian DLQI dengan $\mathrm{p}=1,000$ (Nourmalydza, 2016). Sama dengan penelitian yang dilakukan oleh Yap (2012) yang mengatakan bahwa terdapat korelasi

yang lemah pada akne derajat ringan dan menjadi tidak signifikan pada penderita akne sedang maupun berat karena pada penelitian didapatkan sosial dan budaya dapat menerima keadaannya dengan tulus, selain itu faktor ekonomi juga berpengaruh, sosial ekonomi tinggi akan lebih perhatian terhadap penampilan.

Tetapi berbeda dengan penelitian yang dilakukan oleh Vilar, Santos dan Filho (2015) yang dilakukan di negara Brasil yang mengatakan adanya hubungan antara derajat keparahan akne dengan kualitas hidup DLQI. Dalam penelitian tersebut bahwa adanya hubungan antara derajat akne berat dengan gangguan kualitas hidup berat akan tetapi jika dihubungkan dengan kepercayaan diri tidak didapatkan signifikansi yang terlihat dengan keparahan akne vulgaris (Vilar, Dos Santos and Filho, 2015). Hal ini dapat terjadi karena terdapat beberapa kemungkinan yang terjadi yaitu karakter seseorang yang dapat membuat seseorang untuk berpikir menerima terhadap kondisinya saat ini atau menolak kondisinya sehingga mampu untuk menganggu kualitas hidup.

\section{KESIMPULAN}

Dari hasil penelitian didapatkan $\mathrm{p}=0,101(\mathrm{p}>0,05)$ yang berarti tidak terdapat adanya hubungan antara derajat keparahan akne vulgaris dengan kualitas hidup menggunakan penilaian Dermatology Life Quality Index (DLQI). Karena terdapat beberapa pertanyaan yang tidak sesuai untuk penderita akne vulgaris tetapi menjadi sesuai pada penyakit lain. 
Jurnal Kebidanan Mutiara Mahakam, Vol 8 , No 2, Tahun 2020, Hal 77-83

\section{DAFTAR PUSTAKA}

Harahap, M. (2000) Ilmu Penyakit kulit. Jakarta: Penerbit Hipokrates.

Maulina, B. and Sari, D. R. (2018) 'Derajat Stres Mahasiswa Baru Fakultas Kedokteran Ditinjau Dari Tingkat Penyesuaian Diri Terhadap Tuntutan Akademik', Jurnal Psikologi Pendidikan dan Konseling: Jurnal Kajian Psikologi Pendidikan dan Bimbingan Konseling, 4(1), p. 1. doi: 10.26858/jpkk.v4i1.4753.

Nazaya, M., Praharsini, I. G. A. A. and Rusyati, L. M. M. (2018) 'Profil Gangguan Kualitas Hidup Akibat Akne Vulgaris Pada Mahasiswa Fakultas Kedokteran Universitas Udayana Tahun 2015', E jurnal medika, 7(8), pp. 1-5.

Nourmalydza, I. (2016) Hubungan Antara Derajat Keparahan Akne Vulgaris dengan Kualitas Hidup pada Mahasiswa Program Studi Kedokteran dan Profesi Dokter UIN Syarif Hidayatullah Jakarta Angkatan 2013-2015. Fakultas Kedokteran dan Ilmu Kesehatan Universitas Islam Negeri Syarif Hidayatullah.

Rahmatina (2013) Uji Validitas dan Reliabilitas Dermatology Life Quality Index (DLQI) Berbahasa Indonesia pada Pasien Poliklinik Ilmu Kesehatan Kulit dan Kelamin Rumah Sakit Dr. Cipto Mangunkusumo. Fakultas Kedokteran Universitas Indonesia.

Sitohang, I. B. S. and Wasitatmadja, S. M. (2016) 'Akne Vulgaris', in Ilmu Penyakit Kulit dan Kelamin. Jakarta: Fakultas Kedokteran Universitas Indonesia.

Thappa, D. M. and Adityan, B. (2009) 'Profile of acne vulgaris-A hospital-based study from South India', Indian Journal of Dermatology, Venereology and Leprology, 75(3), pp. 272278. doi: 10.4103/0378-6323.51244.

Vilar, G. N., Dos Santos, L. A. and Filho, J. F. S. (2015) 'Quality of life, self-esteem and psychosocial factors in adolescents with acne vulgaris', Anais Brasileiros de Dermatologia. doi: 10.1590/abd1806-4841.201533726.

WHO (1997) Measuring Quality of Life. Geneva Switzerland : Division of Mental Health and Prevention of Substance Abuse: World Health Organization.

Yap, F. B.-B. (2012) 'The impact of acne vulgaris on the quality of life in Sarawak, Malaysia', Journal of the Saudi Society of Dermatology \& Dermatologic Surgery. doi: 10.1016/j.jssdds.2012.04.003.

Zaenglein, A. L. et al. (2008) 'Acne Vulgaris', in Fitzpatrick's Dermatology in General Medicine. New York: McGraw-Hill. 